\title{
Synthesis of 5-arylacetylenyl-1,2,4-oxadiazoles and their transformations under superelectrophilic activation conditions
}

\author{
Andrey I. Puzanov ${ }^{1}$, Dmitry S. Ryabukhin ${ }^{1,2}$, Anna S. Zalivatskaya ${ }^{1,3}$, \\ Dmitriy N. Zakusilo1,3, Darya S. Mikson'1, Irina A. Boyarskaya ${ }^{3}$ \\ and Aleksander V. Vasilyev ${ }^{*} 1,3, \S$
}

\section{Full Research Paper}

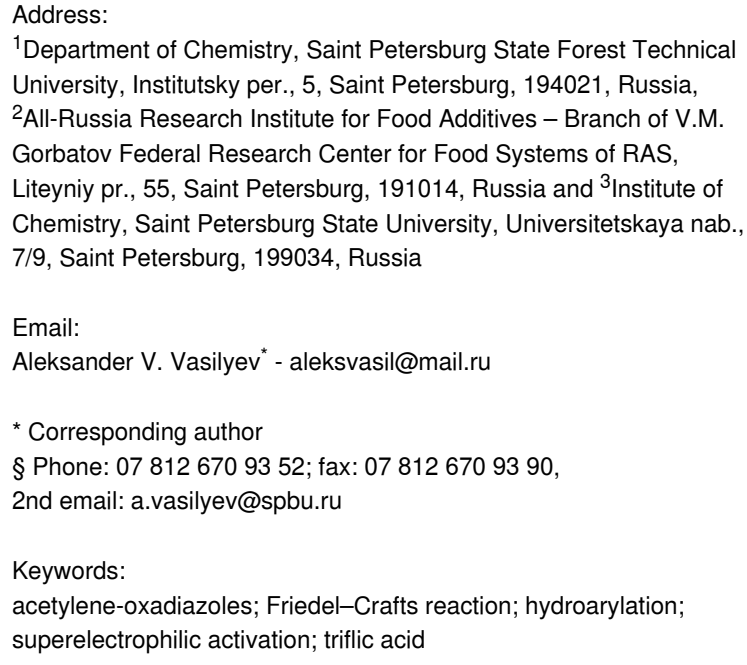

${ }^{1}$ Department of Chemistry, Saint Petersburg State Forest Technical University, Institutsky per., 5, Saint Petersburg, 194021, Russia, ${ }^{2}$ All-Russia Research Institute for Food Additives - Branch of V.M. Gorbatov Federal Research Center for Food Systems of RAS, Liteyniy pr., 55, Saint Petersburg, 191014, Russia and ${ }^{3}$ Institute of Chemistry, Saint Petersburg State University, Universitetskaya nab., 7/9, Saint Petersburg, 199034, Russia

Email:

Aleksander V. Vasilyev* - aleksvasil@mail.ru

* Corresponding author

§ Phone: 0781267093 52; fax: 0781267093 90,

2nd email: a.vasilyev@spbu.ru

Keywords:

acetylene-oxadiazoles; Friedel-Crafts reaction; hydroarylation;

superelectrophilic activation; triflic acid

\author{
Beilstein J. Org. Chem. 2021, 17, 2417-2424. \\ https://doi.org/10.3762/bjoc.17.158 \\ Received: 29 June 2021 \\ Accepted: 08 September 2021 \\ Published: 15 September 2021 \\ Associate Editor: J. A. Murphy \\ (C) 2021 Puzanov et al.; licensee Beilstein-Institut. \\ License and terms: see end of document.
}

\begin{abstract}
Acetylene derivatives of 1,2,4-oxadiazoles, i.e., 5-(2-arylethynyl)-3-aryl-1,2,4-oxadiazoles, have been obtained, for the first time reported, from 5-(2-arylethenyl)-3-aryl-1,2,4-oxadiazoles by their bromination at the carbon-carbon double bond followed by di-dehydrobromination with $\mathrm{NaNH}_{2}$ in liquid $\mathrm{NH}_{3}$. The reaction of the acetylenyl-1,2,4-oxadiazoles with arenes in neat triflic acid $\mathrm{TfOH}\left(\mathrm{CF}_{3} \mathrm{SO}_{3} \mathrm{H}\right)$ at room temperature for $1 \mathrm{~h}$ resulted in the formation of E/Z-5-(2,2-diarylethenyl)-3-aryl-1,2,4-oxadiazoles as products of regioselective hydroarylation of the acetylene bond. The addition of $\mathrm{TfOH}$ to the acetylene bond of these oxadiazoles quantitatively resulted in E/Z-vinyl triflates. The reactions of the cationic intermediates have been studied by DFT calculations and the reaction mechanisms are discussed.
\end{abstract}

\section{Introduction}

1,2,4-Oxadiazoles have a great importance in chemistry, biology and medicine. Many drugs contain an 1,2,4-oxadiazole ring, such as butalamine [1], libexin [2], ataluren [3], oxolamine
[4], and pleconaril [5]. Various oxadiazole derivatives show different kinds of activity against cancer [6,7], tuberculosis [8], Gram-positive bacteria [9], and they are used in treatment of 
epilepsy [10] and Alzheimer disease [11-13]. The synthesis of compounds of the 1,2,4-oxadiazole series is an actual task in organic and medicinal chemistry (see selected reviews on this topic [14-22]). However, among all the varieties of 1,2,4-oxadiazoles, their acetylenic derivatives are quite rare. To the best of our knowledge, there is only one example of 1,2,4-oxadiazole conjugated with an acetylene bond, which is 3-phenylethynyl1,2,4-oxadiazole [23]. Up to the moment, there are no data on the preparation of 1,2,4-oxadiazoles containing a conjugated acetylenic substituent in the position 5 of the heterocyclic ring

Based on our previous works on the chemistry of 1,2,4-oxadiazoles in superacids $[24,25]$, we undertook this study on further investigation of the transformations of these heterocyclic compounds in electrophilic media. The main goals of this work were the synthesis of 5-arylacetylenyl-1,2,4-oxadiazoles and the study of their reactions with/without arenes under the conditions of superelectrophilic activation by the Brønsted superacid $\mathrm{CF}_{3} \mathrm{SO}_{3} \mathrm{H}(\mathrm{TfOH})$, the strong Lewis acids $\mathrm{AlX}_{3}(\mathrm{X}=\mathrm{Cl}, \mathrm{Br})$, or the acidic zeolite $\mathrm{CBV}-720$

\section{Results and Discussion}

The synthesis of 5-arylethynyl-1,2,4-oxadiazoles 3 was based on transformations of the corresponding 5-styryloxadiazoles, i.e., 5-(2-arylethenyl)-3-aryl-1,2,4-oxadiazoles 1a-g (Scheme 1). Bromination of the side chain carbon-carbon double bond in oxadiazoles 1a-g led to pairs of diastereomers of dibromo derivatives $\mathbf{2 a - g}$. Then, several bases were tested for the di-dehydrobromination of compounds $\mathbf{2 a - g}$. However, treatment of $\mathbf{2} \mathbf{a}-\mathbf{g}$ in the following systems, $\mathrm{KOH}-\mathrm{EtOH}$ (reflux, $2 \mathrm{~h}$ ), BuLi-THF $\left(-40^{\circ} \mathrm{C}, 2 \mathrm{~h}\right), t$-BuOK-THF (reflux, $2 \mathrm{~h}$ ), or $\operatorname{LiN}(\mathrm{iPr})_{2}-\mathrm{THF}\left(-40{ }^{\circ} \mathrm{C}, 2 \mathrm{~h}\right)$, afforded complex mixtures of reaction products without desired acetylenyloxadiazoles $\mathbf{3}$. We succeeded to get compounds $\mathbf{3 a - e}$ by the reaction of 2a-e with sodium amide in liquid ammonia $\left[\mathrm{NaNH}_{2}-\mathrm{NH}_{3}\right.$ (liq.)] only at low temperature -70 to $-60{ }^{\circ} \mathrm{C}$ (Scheme 1). However, the yields of target compounds were moderate $32-54 \%$ (for 3a-c,e) or even low $9 \%$ (for 3d). Running this reaction at higher temperature -50 to $-40{ }^{\circ} \mathrm{C}$ led to a decrease of the yields of compounds 3 . Apart from that, compounds $\mathbf{2 f}, \mathbf{g}$ containing a 3-para-bromophenyl moiety in the heterocyclic core gave no corresponding 5-acetylenyloxadiazoles 3 in the system $\mathrm{NaNH}_{2}-\mathrm{NH}_{3}$ (liq.), only mixtures of oligomeric materials were formed. Moreover, compound $\mathbf{3 e}$ was obtained as an inseparable mixture with styryloxadiazole $\mathbf{1 e}$. The latter may be formed from $\mathbf{3 e}$ under the reduction by the solution that contained $\mathrm{NaNH}_{2}$. All these data point out the instability of 5-acetylenyloxadiazoles $\mathbf{3}$ in strong basic and nucleophilic media. Oxadiazoles $\mathbf{3}$, which were initially formed from compounds 2 in the system $\mathrm{NaNH}_{2}-\mathrm{NH}_{3}$ (liq.), underwent further secondary transformations under nucleophilic reaction conditions, even at very low temperature -70 to $-60{ }^{\circ} \mathrm{C}$, that resulted in low to moderate yields of the target acetylene derivatives.

Then, electrophilic reactions of 5-acetylenyloxadiazoles 3a-d in different acids were studied. In our recent study on the electrophilic activation of 5-styryl-1,2,4-oxadiazoles 1 [24], it was shown by means of NMR spectroscopy and DFT calculation that the protonation of these oxadiazoles in Brønsted superacids<smiles>[R]c1ccc(-c2noc(C(Br)C(Br)c3ccc([R])cc3)n2)cc1</smiles><smiles>[R]c1ccc(/C=C/c2nc(-c3ccc([R])cc3)no2)cc1</smiles>

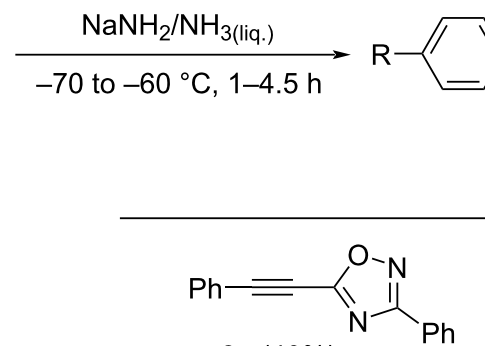

$3 a(40 \%)$

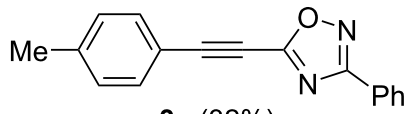

$3 c(32 \%)$

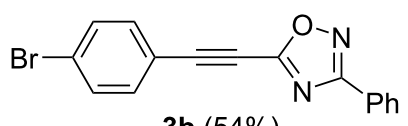

3b $(54 \%)$

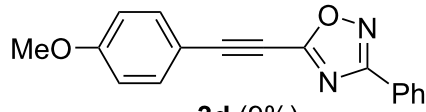

$3 d(9 \%)$

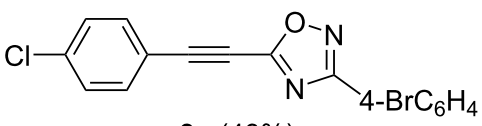

$3 e(48 \%)$ 
TfOH and $\mathrm{FSO}_{3} \mathrm{H}$ gave reactive $\mathrm{N}, \mathrm{C}$-diprotonated species. The protonation of oxadiazoles 1 takes place at the nitrogen $\mathrm{N} 4$ and the $\alpha$-carbon of the side chain $\mathrm{C}=\mathrm{C}$ bond. One would expect the formation of similar dications at the protonation of acetylenyloxadiazoles 3 in Brønsted superacids (see Table 1). Table 1 contains data on DFT calculations of cations Aa-d (N-protonated forms) and Ba-d (N,C-diprotonated forms) derived at the protonation of oxadiazoles 3a-d. Charge delocalization, contribution of atomic orbital into LUMO, global electrophilicity indices $\omega[26,27]$, and Gibbs free energies of protonation reactions with hydroxonium ion $\left(\mathrm{H}_{3} \mathrm{O}^{+}\right) \Delta G_{298}$ were calculated.

Big negative values of $\Delta G_{298}(-86.6$ to $-79.2 \mathrm{~kJ} / \mathrm{mol})$ of the first protonation step show that the formation of $\mathrm{N}$-protonated

Table 1: Selected electronic characteristics for cations $\mathbf{A a - d}$ and $\mathbf{B a}-\mathbf{d}$ calculated by DFT from protonation of oxadiazoles $\mathbf{3 a - d}$

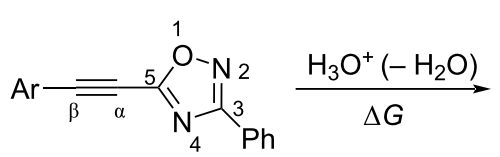

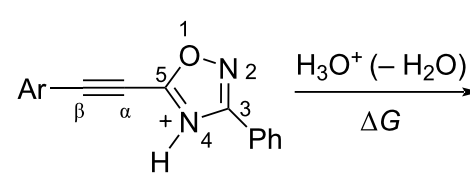<smiles>BrC=CC1=[N+]C(c2ccccc2)=NO1</smiles>

$3 a-d$

Aa-d
Ba-d

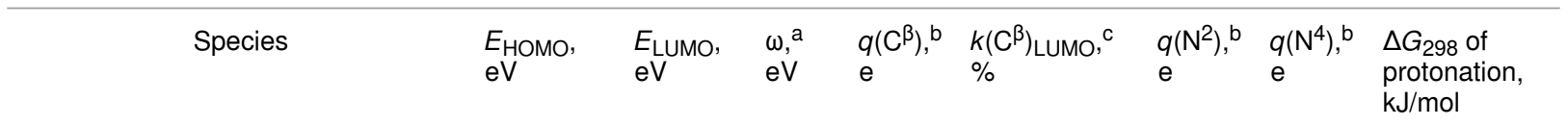

Cations A (N-protonated species)<smiles>C[n+]1c(-c2ccccc2)noc1C#Cc1ccccc1</smiles>
$-7.44$<smiles></smiles><smiles>C=C(C)Br</smiles><smiles></smiles>
Ac<smiles>CCCCO</smiles><smiles>c1ccccc1</smiles><smiles>C[N+]1=C(C=Cc2ccccc2)C(C=Cc2ccccc2)ON1</smiles>

$\mathrm{Ba} \mathrm{Ph}$<smiles>Cc1ccc(C=Cc2onc(O)[n+]2C=Cc2ccccc2)cc1</smiles>

$\mathrm{Bb} \quad \mathrm{Ph}$ 
Table 1: Selected electronic characteristics for cations Aa-d and Ba-d calculated by DFT from protonation of oxadiazoles 3a-d. (continued)<smiles>Cc1noc(/C=C/c2ccc(Br)cc2)[nH+]1</smiles>

Bc $\mathrm{Ph}$

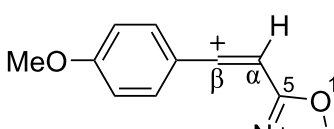

1

$\mathrm{H}_{4}^{-} \mathrm{N}_{3}^{+} \mathrm{N}^{2}$

Bd $\mathrm{Ph}$

\section{$-7.82$}

0.45

24.3

$-7.80$

$-4.63$

6.1

0.40

16.7
0.1

${ }^{\mathrm{a}}$ Global electrophilicity index $\omega=\left(E_{\mathrm{HOMO}}+E_{\mathrm{LUMO}}\right)^{2} / 8\left(E_{\mathrm{LUMO}}-E_{\mathrm{HOMO}}\right) .{ }^{\mathrm{b}}$ Natural charges. ${ }^{\mathrm{c}}$ Contribution of atomic orbital into molecular orbital. species Aa-d is extremely energetically favorable. For the second protonation (reaction $\mathbf{A} \rightarrow \mathbf{B}$ ) leading to dications $\mathbf{B a}-\mathbf{d}$, the $\Delta G_{298}$ values vary from -28.6 to $18.3 \mathrm{~kJ} / \mathrm{mol}$. Although the second protonations are sometimes mildly endergonic (and hence there would be an unfavourable equilibrium between species $\mathbf{A}$ and $\mathbf{B}$ ), the capture of the diaction $\mathbf{B}$ by a nucleophile is likely to be very exergonic and this can drive the reaction through to the products. Calculated electronic characteristic of these dications reveal their high electrophilicity, the indexes $\omega$ are $6.1-8.4 \mathrm{eV}$. Carbon $\mathrm{C}^{\beta}$ bears a large positive charge (0.40-0.47 e) and gives a big contribution into LUMO (16.7-30\%), pointing out that this carbon is a reactive electrophilic center by charge and orbital factors.

Thus, according our previous data on reactions of 5-styryl1,2,4-oxadiazoles 1 [24] and results of the DFT calculations for protonation of 5-acetylenyl-1,2,4-oxadiazoles 3 (Table 1), one would propose the following reaction pathways for compounds 3 in Brønsted superacids (Scheme 2). Protonation of oxadiazole $\mathbf{3}$ affords dication $\mathbf{B}$, which may react with counter anion of acid $\mathrm{X}^{-}$giving rise to vinyl derivatives 4 . In the presence of nucleophilic arene molecules, species B should afford substances $\mathbf{5}$ as products of hydroarylation of the acetylene bond of the starting compounds $\mathbf{3}$.

Indeed, reaction of 5-acetylenyl-1,2,4-oxadiazoles 3a-c with excess of $\mathrm{TfOH}$ at room temperature for $1 \mathrm{~h}$ resulted in the quantitative preparation of $E / Z$-isomers of vinyl triflates $4 \mathbf{a}-\mathbf{c}$ with a predominant formation of $Z$-isomers as product of an anti-addition of $\mathrm{TfOH}$ to the acetylene bond (Scheme 3). E/Z-Stereochemistry of compounds $\mathbf{4 a - c}$ was determined by $\mathrm{H}$,F-NOESY correlation between vinyl proton $(>\mathrm{C}=\mathrm{CH}-)$ and the $\mathrm{CF}_{3}$ group from the TfO substituent (see Supporting Information File 1). It should be noted that attempts of chromatographic separation of triflates $\mathbf{4 a - c}$ into individual $E$ - and $Z$-isomers on silica gel led to a decrease of their yields and a change in $E / Z$-ratio. That reveals instability of these compounds on silica gel.

In the same reaction in $\mathrm{H}_{2} \mathrm{SO}_{4}$ (Scheme 4), oxadiazole 3a gave the product of hydration of the acetylene bond (4d, yield of $65 \%$ ) existing in solution as equilibrium between ketone and enol forms in a ratio of 1.2:1 according to NMR data (see Supporting Information File 1).

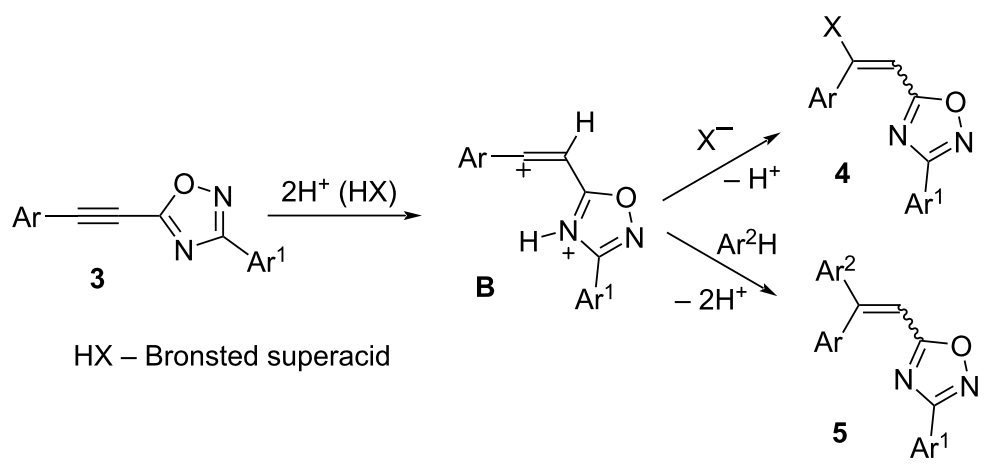

Scheme 2: Plausible reaction mechanism for transformations of 5-acetylenyl-1,2,4-oxadiazoles 3 in Brønsted superacids. 

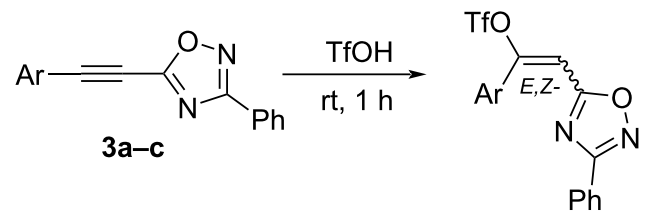

(E/Z)-4a-c

(quantitatively)

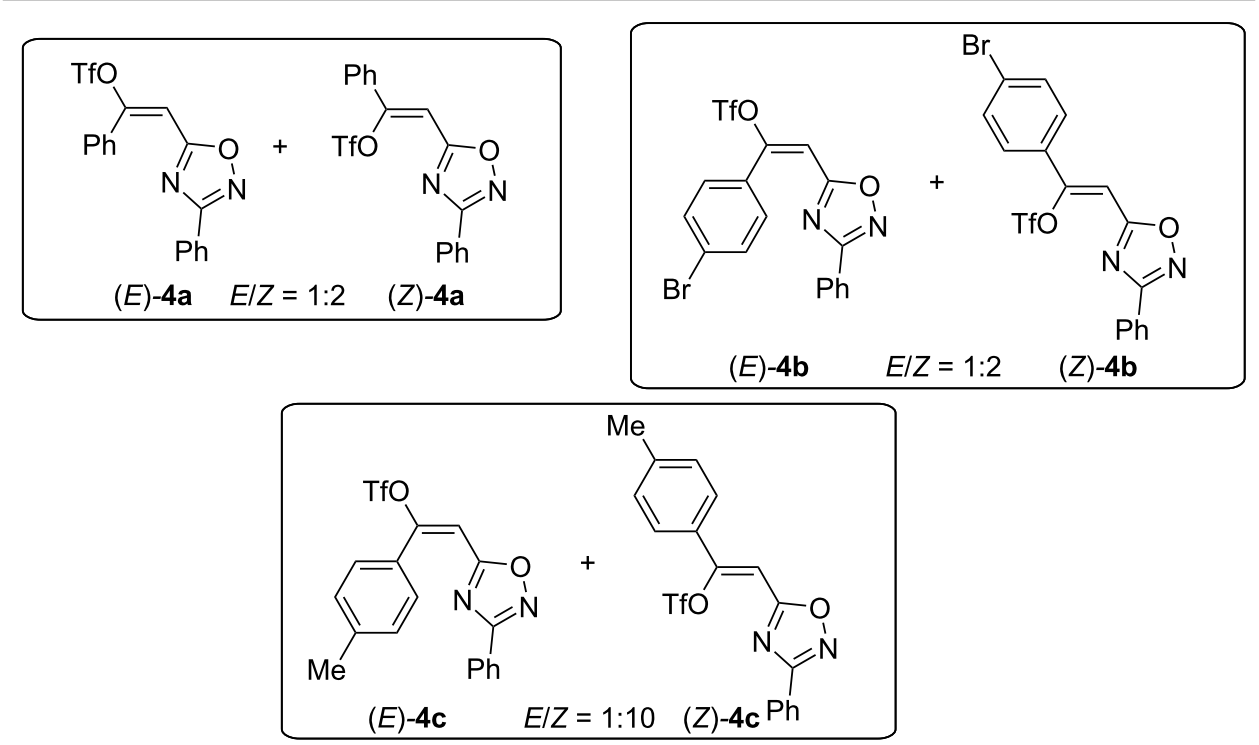

Scheme 3: Quantitative formation of E/Z-vinyl triflates 4a-c from 5-acetylenyl-1,2,4-oxadiazoles 3a-c in TfOH.

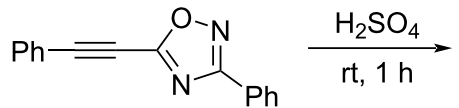

$3 a$<smiles>O=C(Cc1nc(-c2ccccc2)no1)c1ccccc1</smiles>

$\Longrightarrow$

$4 d(65 \%)$

Then, reactions of 5-acetylenyl-1,2,4-oxadiazole 3a-d with arenes (benzene and $o-, m-, p$-xylenes) in $\mathrm{TfOH}$ at room temperature for $1 \mathrm{~h}$ leading to products of hydroarylation of the acetylene bond, compounds $(E / Z)-\mathbf{5 a}-\mathbf{g}$, were carried out (Scheme 5). This reaction gave E/Z-isomers $5 \mathbf{b}-\mathbf{g}$, their stereochemical configuration was determined by H,H NOESY correlations between the vinyl proton and aromatic protons (see Supporting Information File 1). In the case of the reaction with $o$-xylene, pairs of $E / Z$-isomers of two regioisomers, $(E / Z)-5 \mathbf{b}$ and $(E / Z)-5 b 1$, were obtained.

We also checked the reaction of oxadiazole $3 \mathbf{a}$ with benzene under the action of Lewis acids $\mathrm{AlCl}_{3}, \mathrm{AlBr}_{3}$ and acidic zeolite CBV-720 (Table 2). However, these Lewis acids showed unsatisfactory results leading to oligomeric materials (Table 2 , entries 1 and 2). Probably, due to some secondary reactions of the formed compound $\mathbf{5 a}$ with $\mathrm{AlCl}_{3}, \mathrm{AlBr}_{3}$. The yield of target compound $\mathbf{5 a}$ in the reaction with zeolite was lower than in the same reaction in $\mathrm{TfOH}$ (compare entry 3 in Table 2 with data shown in Scheme 5). Thus, among the tested acidic reagents, TfOH showed better results for the hydroarylation of compounds 3 .

Additionally, the reaction of oxadiazole 3a with benzene in $\mathrm{TfOH}(\mathrm{rt}, 1 \mathrm{~h}$ ) in the presence of cyclohexane, as a hydride ion source, was conducted to achieve the ionic hydrogenation of intermediate cationic species. However, no products of ionic hydrogenation were obtained, only the product of the hydrophenylation of the acetylene bond 5a was quantitatively isolated (compare with data shown in Scheme 5). 


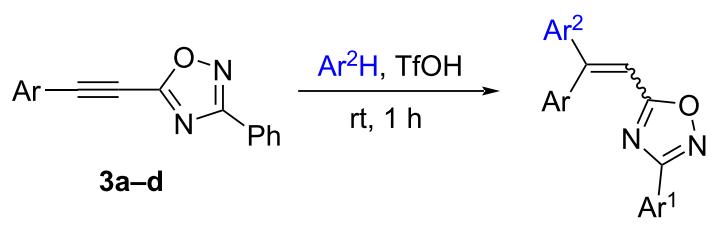

(E/Z)-5a-g
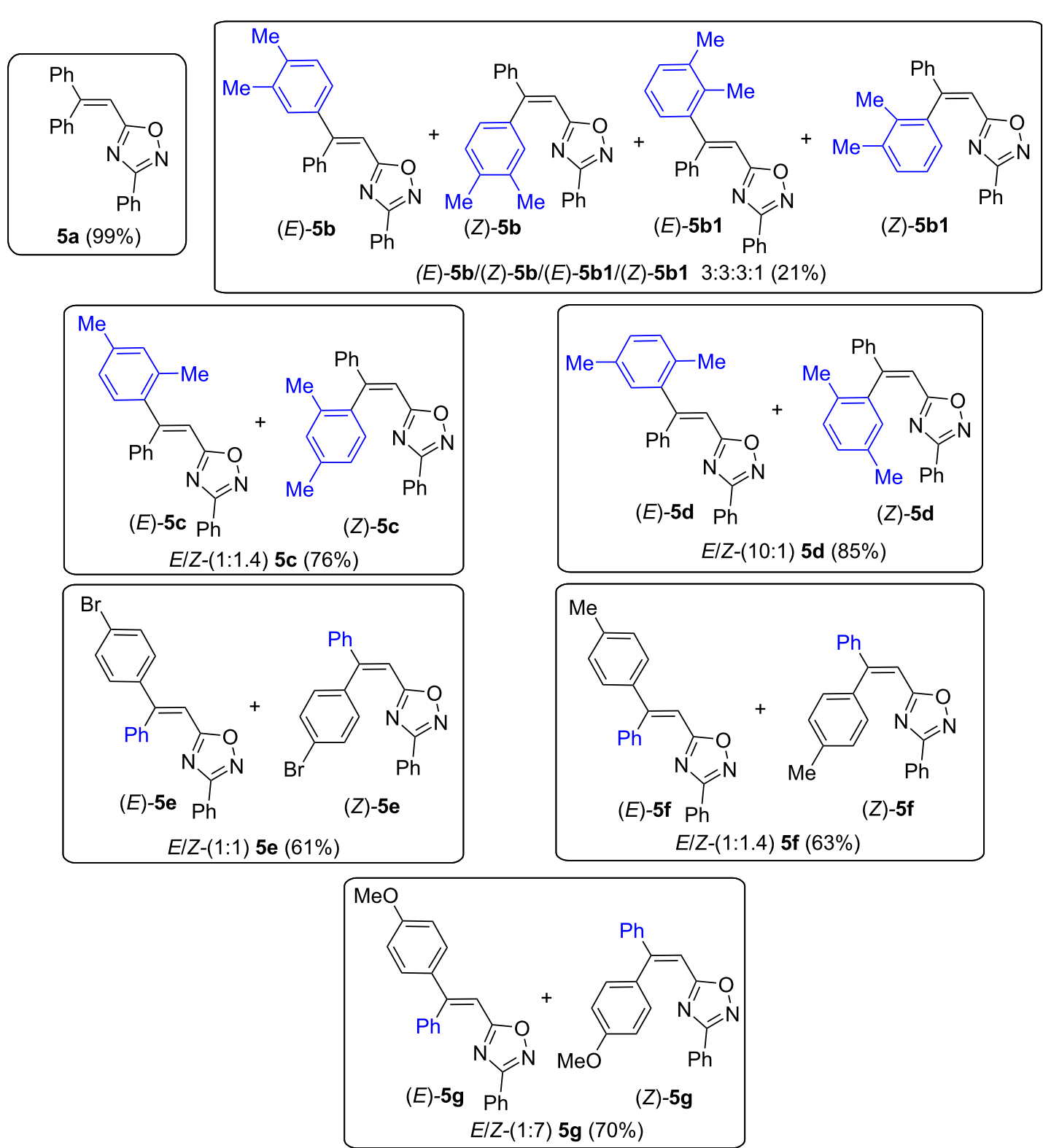

Scheme 5: Hydroarylation of 5-acetylenyl-1,2,4-oxadiazole 3a-d by arenes in TfOH leading to compounds E/Z-5a-g.

\section{Conclusion}

For the first time reported, we have synthesized 5-arylacetylene derivatives of 1,2,4-oxadiazoles, i.e., 5-(2-arylethynyl)-3-aryl1,2,4-oxadiazoles. In the Brønsted superacid TfOH, these oxadiazoles react in a way of electrophilic addition to the acetylene bond. They give products of hydroarylation of the acetylene bond in the reaction with arenes or vinyl triflates in reaction with $\mathrm{TfOH}$ without arenes. 
Table 2: Reactions of 5-acetylenyloxadiazole 3a with benzene under the action of various acids.<smiles></smiles>

\begin{tabular}{ccccc}
\hline Entry & Acid & \multicolumn{2}{c}{ Reaction conditions } & \multirow{2}{*}{ Yield of $\mathbf{5 a}, \%$} \\
\cline { 3 - 4 } & & & \\
\hline 1 & $\mathrm{AlCl}_{3}$ & $\mathrm{~T}$ & 1 & Oligomeric compounds \\
2 & $\mathrm{AlBr}_{3}$ & $\mathrm{rt}$ & 1 & oligomeric compounds \\
3 & Zeolite $\mathrm{CBV}-720$ & 130 & 1 & 56 \\
\end{tabular}

\section{Supporting Information}

\section{Supporting Information File 1}

Experimental procedures, characterization data and ${ }^{1} \mathrm{H}$ and

${ }^{13} \mathrm{C}$ NMR spectra of compounds, as well as data of DFT

calculations.

[https://www.beilstein-journals.org/bjoc/content/ supplementary/1860-5397-17-158-S1.pdf]

\section{Funding}

This work was supported by the Russian Foundation for Basic Research (grant no. 20-03-00074 A).

\section{ORCID ${ }^{\circledR}$ iDs}

Andrey I. Puzanov - https://orcid.org/0000-0001-8879-5941 Dmitry S. Ryabukhin - https://orcid.org/0000-0001-5345-0038 Dmitriy N. Zakusilo - https://orcid.org/0000-0002-3972-9515 Aleksander V. Vasilyev - https://orcid.org/0000-0003-3628-1492

\section{Preprint}

A non-peer-reviewed version of this article has been previously published as a preprint: https://doi.org/10.3762/bxiv.2021.49.v1

\section{References}

1. Palazzo, G.; Corsi, G. Arzneim. Forsch. 1962, 12, 545-549.

2. Coupar, I. M.; Hedges, A.; Metcalfe, H. L.; Turner, P. J. Pharm. Pharmacol. 1969, 21, 474-475. doi:10.1111/j.2042-7158.1969.tb08294.x

3. Jones, A. M.; Helm, J. M. Drugs 2009, 69, 1903-1910. doi:10.2165/11318500-000000000-00000

4. Silvestrini, B. Minerva Med. 1960, 51, 4091-4094.

5. Rotbart, H. A.; Webster, A. D. Clin. Infect. Dis. 2001, 32, 228-235. doi:10.1086/318452
6. Zhang, H.-Z.; Kasibhatla, S.; Kuemmerle, J.; Kemnitzer, W.; Ollis-Mason, K.; Qiu, L.; Crogan-Grundy, C.; Tseng, B.; Drewe, J.; Cai, S. X. J. Med. Chem. 2005, 48, 5215-5223. doi:10.1021/jm050292k

7. Shamsi, F.; Hasan, P.; Queen, A.; Hussain, A.; Khan, P.; Zeya, B.; King, H. M.; Rana, S.; Garrison, J.; Alajmi, M. F.; Rizvi, M. M. A.; Zahid, M.; Imtaiyaz Hassan, M.; Abid, M. Bioorg. Chem. 2020, 98, 103754. doi:10.1016/j.bioorg.2020.103754

8. Atmaram Upare, A.; Gadekar, P. K.; Sivaramakrishnan, H.; Naik, N.; Khedkar, V. M.; Sarkar, D.; Choudhari, A.; Mohana Roopan, S. Bioorg. Chem. 2019, 86, 507-512. doi:10.1016/j.bioorg.2019.01.054

9. Janardhanan, J.; Chang, M.; Mobashery, S. Curr. Opin. Microbiol. 2016, 33, 13-17. doi:10.1016/j.mib.2016.05.009

10. Mohammadi-Khanaposhtani, M.; Shabani, M.; Faizi, M.; Aghaei, l.; Jahani, R.; Sharafi, Z.; Shamsaei Zafarghandi, N.; Mahdavi, M.; Akbarzadeh, T.; Emami, S.; Shafiee, A.; Foroumadi, A. Eur. J. Med. Chem. 2016, 112, 91-98. doi:10.1016/j.ejmech.2016.01.054

11. Querfurth, H. W.; LaFerla, F. M. N. Engl. J. Med. 2010, 362, 329-344. doi:10.1056/nejmra0909142

12. Jiang, C.-S.; Fu, Y.; Zhang, L.; Gong, J.-X.; Wang, Z.-Z.; Xiao, W.; Zhang, H.-Y.; Guo, Y.-W. Bioorg. Med. Chem. Lett. 2015, 25, 216-220. doi:10.1016/j.bmcl.2014.11.068

13. Mei, W.-w.; Ji, S.-s.; Xiao, W.; Wang, X.-d.; Jiang, C.-s.; Ma, W.-q.; Zhang, H.-y.; Gong, J.-x.; Guo, Y.-w. Monatsh. Chem. 2017, 148, 1807-1815. doi:10.1007/s00706-017-1993-x

14. Hemming, K. J. Chem. Res., Synop. 2001, 209-216. doi:10.3184/030823401103169603

15. Kayukova, L. A. Pharm. Chem. J. 2005, 39, 539-547. doi:10.1007/s11094-006-0017-7

16. Hemming, K. 1.2.4-Oxadiazoles. In Five-membered Rings: Triazoles, Oxadiazoles, Thiadiazoles and their Fused Carbocyclic Derivatives; Zhdankin, V. V., Ed.; Comprehensive Heterocyclic Chemistry III, Vol. 5; Elsevier, 2008; pp 243-314. doi:10.1016/b978-008044992-0.00504-6

17. Pace, A.; Pierro, P. Org. Biomol. Chem. 2009, 7, 4337-4348. doi:10.1039/b908937c

18. Bora, R. O.; Dar, B.; Pradhan, V.; Farooqui, M. Mini-Rev. Med. Chem. 2014, 14, 355-369. doi:10.2174/1389557514666140329200745

19. Pace, A.; Buscemi, S.; Piccionello, A. P.; Pibiri, I. Adv. Heterocycl. Chem. 2015, 116, 85-136. doi:10.1016/bs.aihch.2015.05.001 
20. Piccionello, A. P.; Pace, A.; Buscemi, S. Chem. Heterocycl. Compd. 2017, 53, 936-947. doi:10.1007/s10593-017-2154-1

21. Aggarwal, S.; Goyal, A.; Kaur, R. Res. J. Pharm. Technol. 2020, 13, 5026-5033. doi:10.5958/0974-360x.2020.00880.x

22. Lelyukh, M.; Demchuk, I.; Harkov, S.; Chaban, T.; Drapak, I.; Chaban, I.; Shelepeten, L.; Matiychuk, V. Biointerface Res. Appl. Chem. 2020, 10 (4), 5960-5971. doi:10.33263/briac104.960971

23. Claisse, J. A.; Foxton, M. W.; Gregory, G. I.; Sheppard, A. H.; Tiley, E. P.; Warburton, W. K.; Wilson, M. J.

J. Chem. Soc., Perkin Trans. 1 1973, 2241-2249. doi:10.1039/p19730002241

24. Zalivatskaya, A. S.; Ryabukhin, D. S.; Tarasenko, M. V.; Ivanov, A. Y.; Boyarskaya, I. A.; Grinenko, E. V.; Osetrova, L. V.; Kofanov, E. R.; Vasilyev, A. V. Beilstein J. Org. Chem. 2017, 13, 883-894. doi:10.3762/bjoc.13.89

25. Golushko, A. A.; Khoroshilova, O. V.; Vasilyev, A. V. J. Org. Chem. 2019, 84, 7495-7500. doi:10.1021/acs.joc.9b00812

26. Parr, R. G.; Szentpály, L. v.; Liu, S. J. Am. Chem. Soc. 1999, 121, 1922-1924. doi:10.1021/ja983494x

27. Chattaraj, P. K.; Giri, S.; Duley, S. Chem. Rev. 2011, 111, PR43-PR75. doi:10.1021/cr100149p

\section{License and Terms}

This is an Open Access article under the terms of the Creative Commons Attribution License (https://creativecommons.org/licenses/by/4.0). Please note that the reuse, redistribution and reproduction in particular requires that the author(s) and source are credited and that individual graphics may be subject to special legal provisions.

The license is subject to the Beilstein Journal of Organic Chemistry terms and conditions:

(https://www.beilstein-journals.org/bjoc/terms)

The definitive version of this article is the electronic one which can be found at:

https://doi.org/10.3762/bjoc.17.158 